\title{
The Effect of Sport Education on Secondary Six Students" Learning Interest and Collaboration in Football Lessons 暈動教育模式如何影響中六學生學習足球的興趣及協作能力
}

Ka Lun CHAN

Fung Kai Liu Man Shek Tong

Secondary School,

HONGKONG

陳家倫

鳳溪廖萬石堂中學

\author{
Alberto CRUZ \\ Department of Creative Arts \& Physical Education, \\ The Hong Kong Institute of Education, \\ HONGKONG \\ 高達偷 \\ 香港敎育學院體藝學系
}

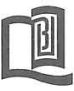

\begin{abstract}
Sport education has attracted attention and interest from physical educators recently. This study aimed at examining the effects of sport education on secondary six students' learning interest and collaboration in football lessons. Participants were 28 male students and they were taught in nine double football lessons with sport education model. Students were grouped into teams and assigned with different roles playing as specified in the model. Data were collected by using the participant observation, classroom videotape recording, student reflective logs, individual and group interviews as to understand the learning process and the students' perceptions on the model within the lessons. Data collected were analyzed by employing the analytic induction and constant comparison method. Results indicated that there were positive effects on students' learning interests and collaboration under this teaching model. Results were discussed in the following aspects: (1) students' participation within lessons, (2) how students' learning interest generated under this model, (3) how to develop collaboration of the team members, and (4) how to develop collaboration of different roles taking in the teams. The results hold implications for the physical education teachers and teacher educators of implementation and promotion of the model.
\end{abstract}

\section{摘 要}

本研究旨在探討運動呚育模式對二十八位中六男生之足球學習興趣與協作能力影響。透過參與式觀察、課堂錄影、學生個人 反思報告、個別角色及團隊訪談, 了解學生學習過程及對此模式之感受及意見。學生接受運動敉育後, 其學習興趣及協作能力均 有正面影響。結果討論如下：一、學生參與運動情沉；二、運動敎育對學習興趣的影響; 三、如何影響隊員間協作能力; 四、如 何影響不同角色間協作能力。研究結果對體育敎師及師資培訓者有重要啟示。

現今香港強調敉育改革, 學習的模式亦不斷推陳出新 地變。體育敎學的目標亦正朝着培養學生終生學習及發展學 生的共通能力, 但研究顯示學生對體育學習的興趣卻隨着年 紀日長而不斷下降(Armstrong, Balding, Gentle \& Kirby 1990; Greenockle, Lee, \& Lomax, 1990)着憑研究者敉學 經驗及觀察, 亦發現高年級學生對體育學習興趣較低年級學 生低, 這正顯示一成不變的體育敎學模式受到衝擊。

「學校課程必須協助學生建立正確的價值觀和態度， 貫徹終身學習的精神, 從而學會如何學習; 培養各種共通能 力, 以便獲取和建構知識, 奠定全人發展的基礎」(課程發 展議會, 2001)。這正好帶出現今的教育改革下, 已不再
是強調知識的敎授(技巧), 而是在於如何協助、促進學生的 學習。而在體育中特別注重發展學生四項的共通能力, 即協 作、溝通、創造及批判性思考能力(課程發展議會, 2002)。 因此研究者深信體育敎學已不僅是著重技巧的傳授, 亦需啟 發學生的思維及發展不同的共通能力。近年紐西蘭 (Grant, 1992)及澳洲 (Alexander， Taggart，\& Thorpe，1996)體育 學者開始對運動敎育模式進行不同研究，發現此敎育模式對 發展共通能力有一定的幫助。此等研究結果漸漸引起英國有 關學者的關注(Kinchin, Penny, \& Clarke, 2001), 台灣學 者曾智豐 (2003)也整理了有關實施運動敎育模式後的實證研 究, 但以上研究多是探討運動敎育模式對技術表現影響, 然 而很少學者研究究竟哪種敎學模式才是學生所㗽往的(Browne, 
Carlson \& Hastie, 2004), 因此研究者正想透過這研究了 解中學生對此運動敉育模式的意見及感受。

運動教育模式的起始概念來自於以遊戲教育為主的課程 (Siedentop, 1994; Jewett, Bain \& Ennis, 1995 ; Metzler, 2000 ；曾智豐，2003；吳明安，2004）, Siedentop（2002)指 出體育課不應只以遊戲為目的, 而應透過體育運動讓學生 學習社會生活, 建立群體文化。運動敉育模式希望發展學 生成為一個有能力(competent)、有文化修養(literate)及具運 動熱誠、樂於參與(enthusiastic)的人(Siedentop，1994），培養 學習者成為一個全方位的運動參與者, 樂於接受責任(李勝 雄, 2002)。運動敉育模式的敉學策略以合作學習為主, 輔以 多變的敉學方法如間接敉學法、同辟敉學(Metzler，2000)、 創造思考教學(顏政通及邱文信，2004)等。Townsend等人 (2003)亦指出此模式的最大意義是增加學生的參與機會, 對 學生的學習與趣有正面的影響。

越來越多有關運動敉育模式的有效程度、內容及對象 影響的研究相繼出現。Carlson \& Hastie (1997)的研究中 指出澳洲高校學生很享受䢐動敉育模式所帶來的樂趣, 特別 是身負重任角色的學生, 他們指出透過此模式更能學習該 角色的特質及可享受成為一個㸚師的角色。Clake \& Quill (2003)在其研究中顯示運用運動敉育模式敉學, 對學生的學 習動機、互相協作及支持有很大的好處, 特別是對於一些技 術表現較差的同學, 可在其他方面如帶領熱身、文件紀錄等 作出貢獻; 亦可能因為一個團隊中經常合作, 令各隊員的關 係更為融洽。Grant (1992)亦提到透過團隊合作, 增加組員 間的互動關係，鼓勵一些不太喜歡運動的學生的參與及興 趣提升。根據Alexander \& Luckman (2001)的研究顯示, $83 \%$ 的敉師認為這模式比傳統的敉學更能吸引學生對體育活 動(課)產生興趣。Hastie (1998A)亦指出參與運動呚育模式的 學生很享受課堂的樂趣, 因為在課堂中有更大的自主性, 同 儕間的學習有較大空間的發揮, 不像以往只有敋師直接敉授 般泛味。Wallhead \& Ntoumanis ( 2004)亦指出透過運動 敎育模式學習的學生, 與傳統敎學模式學習的學生比較下, 對學習興趣有顯著的提升。

為配合研究問題, 本研究以質的研究為主, 主要目的是 探討中六學生在運動敉育模式下學習足球對其學習興趣及協 作能力是否有所影響, 因此本研究目的包含以下三點：

1 以中六級的兩班男生為對象, 探討運動教育模式對他們 學習足球的興趣的效果。

2 以中六級的兩班男生為對象, 探討利用運動敉育模式敉 授足球，對培養他們協作能力的效果。

3 運用運動敉育模式, 對不同技能水平的中六學生的學習 足球興趣及協作能力是否有影響。

\section{研究範園}

本研究以Siedentop(1994)提出的運動敉育模式為基礎, 進行教學設計及實施敎學。學習單元以球季形式進行, 在球 季中把學生分為三隊, 每隊隊中各人須擔當不同的角色, 如 領隊、呚練、球證、球員等。在球季的進行過程中收集不同 角色的學生對這模式的感受及看法, 主要集中在興趣和協作 能力的評量。

本研究將以二十八名年齢介乎17-18歲中六男生為對 象。這二十八人分為三隊, 隊員在每隊中擔當不同角色及均 有機會成為研究對象, 為了選取最能合乎研究目的的樣本, 研究對象是經過立意抽樣(Fraenkel \& Wallen, 2003), 希望 涉獵擔當不同角色同學對此模式的意見, 特別是一些本身對 體育課缺乏興趣的學生。

本研究的敉學項目為足球, 並以應用、遊戲、培養戰 術意識及比賽的模式進行, 當中亦結合了理解式球類呚學法 (Teaching Games for Understanding)進行教學。這項研究 的設計是透過為期約三個月的足球季, 由 2005 年1月至2005 年 4 月, 共9次雙敉節課, 其中 7 次為實施敉學期, 而另外 2 次 為決賽時期。

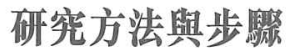

\section{研究流程}

本研究透過運動敉育模式過程, 了解學生在整個球季 後對學習足球的興趣及感受, 及對協作能力的培養有否任何 意見及影響。本研究採用質性研究, 以半結構式訪談大綱進 行訪談、資料菟集, 希望透過深度訪談(in-depth interview) 取得所要分析資料。在閲讀相關文獻後決定研究方向並編定 研究計劃、教學計劃及學習評估表, 這參考了不同的學者 (Bennett \& Hastie, 1997; Hastie, 2000; Metzler, 2000； 曾智豐，2003)的課程設計改編而成，基本模式如表1：

\section{表1. 球季安排。}

\begin{tabular}{|c|c|}
\hline 循環週 & 內容 \\
\hline 1 & $\begin{array}{l}\text { 課程介紹、模式簡介, 敎師觀察及利用學 } \\
\text { 生自評表評估同學能力以協助分組 }\end{array}$ \\
\hline $2-7$ & $\begin{array}{l}\text { 每課的結構安排分為兩至三部份, 第一部 } \\
\text { 份為遊戲、技巧、意識的練習; 第二部份 } \\
\text { 由每隊自行安排的練習, 以備戰最後的比 } \\
\text { 賽; 第三部份為一些知識性的如球例、比 } \\
\text { 賽陣形、角色分工等。 }\end{array}$ \\
\hline $8-9$ & $\begin{array}{l}\text { 為比賽週期, 賽制及規則由競賽組織委員 } \\
\text { 會負責, 頒獎 }\end{array}$ \\
\hline
\end{tabular}


在學習開展前, 各同學填寫一份與足球有關能力的自 我評估表, 這評估表是參考不同文獻(Mohr, Townsend \& Bulger, 2001 ; Lund \& Kirk, 2002)改編而成的。首研究 者為敎師, 首先進行敎學的觀察, 以便了解各同學的能力, 從而協助分組。在正式的教學實施時, 利用錄影機把敎學過 程攝錄下來, 透過觀察並依照觀察所發現的問題進行訪談。 此外, 還有文件檔案資料的蒐集, 在每次進行訪談後, 研 究者都檢閲學生的反思訪談日誌紀錄(Fraenkel \& Wallen, 2003), 以幫助凝聚問題焦點與分析資料及確定研究者目前所 收集資料以及得出的結論是否符合實際情沉。

\section{研究對象}

本研究參與對象為中六級兩班男生共 28 人, 年齡介乎 17 至18歲, 他們將會分成三組, 分組的方法是採用異質分組的 方式, 每組約 9 至 10 人。分組方法是透過自我評估表及敉師 的觀察所訂立的, 而各組擁有足球校隊成員的人數亦相約, 分組依據自我評估表內的四大範疇(技術、戰術、體適能要素 及個人特質)作平均分配, 即每組中各有技術高及低的同學。 運動呚育模式的分隊不同於傳統體育課分組, 它多了「角色 扮演」的重要社會意義過程(何子安, 2002), 也讓低技能學 生有機會參與不同的角色如記錄員、裁判、球隊管理等。

\section{研究工具}

\section{本研究中所使用到的研究工具如下:}

訪談大綱本研究採用半結構的訪談方式, 這種口 頭問卷是由一系列問答題組成, 引導受訪者具體的回答, 這 訪談的方式能搜集廣泛且較有系統性的資料。訪談大綱有助 資料菟集, 其內容關係到資料的菟集是否達到研究的目的與 期望。由於採用的是深度訪談的方式, 所以訪談之前必須先 針對研究主題與方向, 擬定開放性問題以形成大綱(王文科, 2000)。

訪談日誌每一次的訪談後, 隨即製作訪談日誌, 利用最佳的記憶程度, 完成這重要的工作。為什麼這工作十 分重要? 主因是質性研究中, 情境的掌握是資訊獲得與研究 融入的重要關鍵(胡立仕, 2004)。透過訪談日誌, 針對訪談 對象的互動過程加以記錄, 如受訪者的表情、非語言訊息 等。在進行資料分析時, 把當時的情境, 受訪者與首研究者 的個人因素等一併做考慮, 以求呈現研究的真實性。

錄音設備訪談閒研究者與被訪者的對話內容是十 分重要, 是研究主題訊息的命脈, 所以真實的紀錄對話過程 是必要的。然而, 在錄音前必須確定受訪者知道錄音的必要 及同意研究者做法, 以及錄音設備是可正常運作的。
文件蒐集本研究利用學生在其中兩個課堂中不同 形式的個人反思報告以了解他㑚的意見及感受, 亦運用了 改編自Mohr，Townsend \& Bulger(2001)的自我評估表及 Metzler(2000)、Lund \& Kirk (2002)的比賽態度評估表作蒐 集資料之用。這些文件的主要用途是驗證其他資料來源的真 實性及可靠性。

Bennett \& Hastie(1997)指出個人反思報告能把每次學 生完成該課堂後的感受作一紀錄。在整個球季結束後, 可收 取學生的報告以了解其對此教育模式的感受, 藉以量度學生 的興趣及在活動中的合作程度。敎師在敎學過程中指引學生 如何紀錄個人報告, 形式有三種。第一, 不給予任何限制, 要求學生以五十字紀錄當天課堂的得着及感受; 第二, 以問 題形式讓學生記下該課的學習經歷, 如經過此課堂後, 有甚 麼令你感受最深? 你享受參與這課堂的原因? 透過類似問題 以蒐集證據; 第三, 讓學生利用不同的形容詞去表達其對這 一課堂的感受。本研究所菟集的個人報告包括課後檢討及整 個球季的檢討。

參與式觀察敎師用參與式觀察 (Fraenkel \& Wallen, 2003), 了解學生在參與過程中是否能互相合作、及 對學習足球的興趣是否更為濃厚。觀察法具有客觀性及直接 性, Lincolin \& Guba (1985)指出研究對象始終處於自然狀 態中, 不受人為的干擾和控制, 其活動是真實、自然的。

\section{資料蒐集程序}

資料的蒐集可分為四方面：第一是訪談、第二是參與 式觀察、第三是個人報告, 第四是評估表。首研究者共進行 兩次訪談, 在訪談中, 學生可隨意分享其對這敉學模式的意 見, 務求在一個輕鬆的環境下誠實作答。本研究所揀選作訪 談對象分為團隊及個人兩方面, 每隊中的其中 4 名不同角色 成員均會成訪談對象, 其目的是加強資料搜集的一致性。個 人的訪談對象有四人, 包括敎練、球員、競賽組織委員會成 員及平時較不喜歡參與運動者, 而團隊訪談中則訪問其中一 隊。在第一次訪談結束後, 研究者需針對性地製作訪談日 誌, 以作為第二次訪談的參考與資料分析的輔助。第二次訪 談用於補足第一次之缺漏, Fraenkel \& Wallen ( 2003 ) 指出如果同一個人在不同時間的報告不一致, 這可能暗示這 人不是個可靠的報訊者, 因此第二次訪談亦有助於作出校 對。

觀察的範圍將分為兩大部份, 整體觀察及個別角色觀 察。觀察的內容為在活動過程中學生的表現, 包括競賽組織 委員會在商討比賽賽制及細則的情形、每隊中各隊員參與的 投入程度及安排是否有協作。此外, 亦會觀察在過程中與人 合作的次數。而個別角色的觀察在於觀察教練、裁判、球員 及運動能力較遜的隊員是否積極參與其中, 以顯示學生對足 球的興趣是否有所影響。個人報告的菟集將會在球季中及季 
尾進行，而兩次的模式亦有所不同。最終的目標是期望獲取 學生在整個球季後, 對學習足球的興趣是否有所影響, 以及 在協作能力方面是否有所加強。而在學習前及學習後期均要 求學生填寫一份與足球有關能力的自我評估表, 在決賽時期 完結後, 每人亦會自評及互評在比賽中的態度表現。

\section{資料分析程序}

研究者採用「持續比較法」(constant comparison method) (Strauss \& Corbin, 1990) 分析菟集資料。首先 將訪談日誌及在觀察過後所撰寫的筆記整理, 然後把個人報 告中及評估表中得出的數據及內容加以整理, 抽取與本研究 主題之重點加以陳述, 最後將訪談錄音帶轉成逐字稿形式。 在資料分析步驟中, 研究者反覆熟讀訪談的逐字稿, 試圖透 過逐字稿進入並了解受訪者的個人世界, 以達致最全神的 演繹及詮釋。在觀察的過程中, 由於教師敉學與學生活動 範圍大, 很難製作現場筆記, 故此, 透過錄影帶彌補這方 面的不足。利用重複播放錄影帶, 作持續研究與分析之用( Fraenkel \& Wallen, 2003 ) 0 之後研究者各自再畫出重要 敘述句, 將所得到資料, 經過比較、歸納來分門別類, 並發 展主題, 最後綜合每一位受訪者的分析結果, 以及其個人報 告和課堂表現, 加上每個同學對此模式的看法和感受, 從中 整理。研究者經數次討論, 歸納出運動教育模式對學生學習 足球的興趣及協作能力的影響。為提高本研究的信賴度, 研 究者主要採取不同資料檢核策略。研究者採用多樣方式菟集 資料, 藉由不同資料來源及途徑使資料更能反映真實。在蒐 集資料過程中, 將各種資料不斷分析交互比較, 使研究者發 現更豐富的內涵, 及做初步結論前多次討論, 以減少主觀判 斷; 引用資料時, 採取直接引用原始資料或直接引述當事人 的話語方式, 期望能反映研究情境的真實性。

\section{結果與傠論}

\section{學生運動參與現沉}

透過在整個球季前的觀察、學生自行填宾的自我評估表 及訪談資料, 大致上可把同學對運動、體育課堂的參與態度 分為三大類：負面、主動及被動。有少部份的學生自評在足 球的技術、戰術及體能上均較差, 他們對體育課堂的參與較 為被動, 甚至是抗拒, 對於運動的敉育價值存在疑問, 並認 為是可有可無。學生阿明是其中一位中六學生, 他對於運動 參與有這樣的見解 :

「由我小學到現在, 運動給我的印象是沉悶、沒有意 義的。參與運動的目的乃因體育課是學校課程之一, 是必修 課, 因此才免為其難參與。我並不是一個運動愛好者, 每次 的運動參與只帶給我被人取笑、排斥的感覺, 有時真的感到 很孤單及失敗。」(角色訪談 --.- 平時較不喜歡參與運動者 阿明)
另一位學生阿強亦有相類似負面的感受：

「每次參與隊際運動時, 分組總有很大的困難, 通常我 也是最後被揀選的一位, 我感到不被重視。當然, 我知道自 己並不是在運動方面有好的表現, 加上自己也欠自信可做得 到, 但也不希望被看扁。」(角色訪談 --- 平時較不喜歡參 與運動者阿強)

當然, 另一類的學生與上述所講的大大不同, 他們對運 動充滿熱誠及信心。不論何時何地也很享受運動所帶給他們 的樂趣, 他們很主動、積極和投入於各體育活動中, 在課堂 內外, 甚至是休息的時間也接觸運動。從呚師的觀察中, 這 批同學的主動性較強, 亦很懂得凝造氣氛, 而部份更是學校 校隊的成員。

而最後一類的學生可歸納為對運動沒太大的喜與惡, 他 們不介意去參與運動, 但亦不會表露出十分熱衷。這類學生 亦較容易受其他因素影響而參與運動, 可形容他們為擁有兩 種性格的人。這可從阿泉的團隊訪談對話中看到：

教師：你喜歡參與運動的原因是什麼？

阿泉：其實沒有什麼特別原因, 有時一班朋友一起去運 動, 便跟隨一起, 有時是因為覺得悶, 所以想找些 活動玩。

教師：你會把運動放在你生活中的第幾位? 為什麼?

阿泉：(停頓一會, 鎖起眉頭)我想沒有一個固定的位置 呢! 需視乎不同情況, 如有太多功課未完成、身 體很疲倦或有更重要的事去做, 這樣 我便會選擇把運動放在較後的位置, (微 笑一下)我相信心情亦會有所影響呢! 哈哈!

在整班28人當中, 大多數人是屬於對運動參與欠主動的 人, 但不至於憎恨體育, 只是較為被動及習慣單向性的敎學 方式。28人當中, 有 6 人是現役或曾是足球隊的成員, 另外 有3人是其他校隊的成員。整體而言, 他們對體育課的觀感 是正面的, 並不太抗拒, 但卻是被動式的學習。

\section{運動㪍育如何影響學生學習足球的與趣}

在單元學習開展前, 各學生均填寫一份自我評估表, 其中一項為「對足球的興趣」, 這評估只是一個很個人的感 覺, 以 5 分代表非常有與趣, 而 1 分代表完全沒有興趣。全 班 28 人的平均得分為3.34分, 顯示大部份學生對足球也感興 趣, 由於評估表是以記名方式填寫的, 因此敉師可透過日常 課堂觀察學生表現以校對其自我評估之分數。在評分中反映 出一個很重要的數據, 一些平日被認為是運動較差的同學大 多在「對足球的興趣」這項目中給予自己1至2分; 相反地, 
一些校隊成員和運動能力較強的同學, 則在這項目中給予自 己4至5分。這正好顯示出運動技巧較差的同學對學習運動的 興趣並不太熱衣, 與前節所述的不謀而合。在球季的完結 後, 各學生再填寫這評估表一次, 而這次的平均得分為 3.86 分, 顯示大部份學生在經過運動敎育課程模式後, 對學習足 球的興趣有少許的提升。當然這只是一個概括的感覺, 但也 可顯示出其對學習足球的影響。另一方面, 在學生自評及互 評所填回的比賽態度評估表中, 可看見 22 人表示能做到投入 比賽, 盡力而為, 及26人表示經過決賽期後, 對學習足球有 更濃厚的興趣, 研究者相信也可驗證此模式對學生學習足球 興趣的影響。

在正式實施此課程模式時, 開始時已向各同學闡釋整個 球季的安排及特點, 務求讓學生更清晰自己的角色, 作適當 的準備。起初他們並不是太投入及積極參與活動, 但在 1 至 2 節後同學們已開始掌握及了解這模式。在較高自主性的同學 帶領下, 令各參與者更能維持對學習足球的興趣及積極設法 改進自己的表現。在球季的中段, 首研究者給予一份個人報 告, 讓參與者表達對該課堂的感受及意見。報告中最多人用 來表達的形容詞歸納為以下幾類：

第一類為喜悦的心情, 如「開心」、「有趣」、「快樂」 等;

第二類為正面的看法, 如「積極」、「投入」、「陶醉」、 「有意義」等；

第三類為對小組的感受, 如「團結合作」、「應多溝通」、 「有同心合力」等；

第匹類為一些較特別及較通俗的形容, 如「正」、「唔夠 喉」、「時間太短」、「好凍」等。然而這些形容詞亦不是 對運動教育課程模式存有貶義, 至於「好凍」的出現, 我相 信是由於實施課堂的當天天氣只得攝氏度, 實在較為寒冷。

由此可見, 學生經歷這運動敎育課程模式足球課後, 有 更正面的感受, 亦很享受這足球課所帶來的樂趣。超過八成 同學以喜悦心情的形容詞形容該課堂, 亦有超過半數的同學 表示在課中表現很積極及投入, 部份更表示時間不足, 想延 續這單元的課堂。綜合而言, 通過這足球課後, 令同學更熱 愛及更積極學習足球。

在球季結束後, 每位學生均會填寫一個人報告, 在報告 中分析各人對足球課的不同感受。在 28 人中, 所有人均指很 享受及投入於這敉學模式, 其中 27 人表示對學習足球有更濃 厚的興趣，1人表示還可以，而部份同學對這足球季有以下 的看法：

「這足球季有點兒短促, 而且參與隊數較少, 但同學的 參與卻十分積極, 令我也更投入當中的訓練和比賽, 這也是 以前踢足球所欠缺的。」(個人報告二 --- 偉)
「這球季讓我有機會擔當比賽組織的策劃者, 可嘗試 訂定賽程, 我建議打的雙循環的賽事深受同學歡迎呢! 看見 他們這樣開心, 很有成功感, 亦加深了我對足球這運動的認 識呢！」(角色訪談 -.- 競賽組織委員會成員阿龍)

「由同學負責去訂定賽程, 由各隊自行去訂立不同的 戰術, 令我們有更大的空間去發揮, 雖然有些戰術不攻自 破, 但我很開心是因為不用每次也是由老師控制我們。加上 由我們自己去商討自己所踢的位置及打法, 我覺得很有趣, 好似打機, 哈哈!」

(個人報告二 --- 景豪)

綜合各學生的意見, 他們在這模式下學習興趣的由來 有三方面, 第一, 利用很多不同遊戲來學習足球技術及意 識。阿君在其個人報告中指出：「這堂裏我很開心, 因為設 計的足球遊戲很刺激及有趣, 如果堂堂也是這樣就好了。」 高鳳華(2004)指出如果敉學中有些活動佔用較多的時間而使 學習顯得枯燥時, 可將活動設計成活潑的、遊戲性的練習, 借以激發學生的學習興趣。第二, 有機會讓學生互相學習、 指導, 讓他們可多思考如何協助隊友做得更好。團隊訪談例 子:

「我很開心，因我有機會當這隊的敉練，需要經常思 考如何幫我的隊友踢得更好, 又要想下有什麼戰術去爭勝。 當我看見我的隊友很專注聽我的敎導時, 那一刻很有滿足感 呢! 或許我是足球校隊的關係而令他們信任我, 但我最最最 開心的是，當看見技術水平較低的隊友在比賽中成功防守 時, 他所展露的笑容、投入感, 是最令我覺得興奮的。」

這和Browne, Carlson, \& Hastie (2004)所作的研究亦 很相似，學生普遍反映運動敋育模式帶給他們更大的自主性 及有足夠機會讓他們演繹自己的角色。Sinslnikov \& Hastie (2005)亦指出透過運動敉育模式敎授單車時, 學生很緊張自 己在所屬角色上的表現, 而敎師則指出師生之間在敎學的過 程中顯得更有熱誠、更願意學習。

第三, 在足球季尾段的决賽時期, 各隊有共同目標, 享受一起努力爭取勝利, 一起學習面對失敗。因大家在同一 隊的時間長久, 彼此間的友誼及感情逐漸加深。

「我在這球季中可認識到更多朋友, 由於我是在今年 才轉到這學校，因此對這班不是認識太深。」(個人報告二 --- 百橋)

「當我隊取得入球的一刻，那感覺實在是太美妙了， 雖不是我取得入球, 但我的心興奮得像會考拿到 $6 \mathrm{~A}$ 呢! 」 (個人報告二 --- 永富) 
Siedentop \& Kinchin (2003)亦指出透過在團隊中, 各隊員願意去互相幫助及學習, 以求令球隊成功。研究者 相信這令不同能力的學生感到受重視, Siedentop (2002)的 研究亦認為學生享受在隊中的角色, 更願意從同仯的身上學 習。究其原因, 相比敎師的指導, 同儕間的語氣可能比老師 的客氣, 壓力也減少一點, 因不用怕被教師指責未能完成某 動作。

此外, 部份學生亦對這足球季有一些感受及建議, 當 中亦不乏對學習期間及如何改善這足球季的意見, 這正顯示 這模式刺激他們對學習足球的訴求, 以下是他們從訪談及個 人報告中留下的意見：

正道(個人報告二)：「球季在大致上是成功的, 因為可 以令同學全心投入, 爭取勝利, 甚至令同學提升對足球的興 趣, 這些都是成功的地方。但當中仍有些不足, 如球季中課 堂相隔太遠, 有時候甚至要相隔1個月呢!」

阿明(角色訪談)：「感覺上很不錯, 不過好像時間不太 充足, 一場比賽的時間很快就過了。整體而言都很不錯, 不 過如果可以改進一下球證的判決質素會更好。」

從學生的感受及意見中得知, 他們對課程的設計有期 望, 因而提出他們的意見, 顯示學生亦很希望學習更多及學 得更有趣味性, 如他們不想球證的判決影響了學習的興趣、 時間的安排等, 正好展現了學生對學習的訴求。Wallhead \& Ntoumanis (2004)的研究亦指出這模式有很完善的組織 結構, 如能配合教師適時及有效的指引, 對提高學生的學習 動機有很大的幫助, 這亦正與此研究中學生的感受互相呼 應。

從以上的種種例證可以看到學生普遍均認為這運動敉 育課程模式令他們更熱愛及享受學習, 更加強了學習足球 的興趣, 不論是技術、戰術及球例認識上。這亦與Browne, Carlson \& Hastie (2004)' Hastie (1998B)及MacPhail, Kinchin \& Kirk (2003)的研究中的觀點互相吻合, 當然課 程編排的內容及連貫性也是影響他們學習興趣的原因之一 呢!

\section{運動教育對學生協作能力培養的影響}

在球季的開始前, 全班須分成3隊, 而各隊均需訂定所 屬隊伍的隊名。過程中看見各隊隊員各自提出自己的意見, 互相討諭, 分析用甚麼名稱較有特色及代表性, 研究者深信 這一刻已是學生協作能力培養的起步點。當然, 並不能單單 以此來斷言, 但在球季中、訪談中、及文件的蒐集中得出不 同的要點, 現詳述如下:

在球季前學生填寫的自我評估表中，以5分代表非常 好, 而 1 分代表未如理想。其中一項為「合作能力」, 全班
28 人的平均得分為 3.28 分, 這顯示出同學對與人合作能力的 信心不是太強，而球季的完結後的平均得分為3.53分，比先 前有些微調升, 究其原因, 也許是這足球季的設計上有較多 機會需要學生與別人協作、商討, 因而增加了實質與人協作 的經驗, 加強了信心。此外, 在比賽態度評估表中顯示,

「在運動競賽時, 我願意與別人合作」這問題中, 全班有九 成以上的同學均表示能做到, 「在運動競賽時, 我願意以團 隊成績為優先考慮」這項中, 亦有八成以上的同學能做到, 証明學生能在球季中學習發揮團隊協作的能力。在團隊的訪 談中，學生這樣回答老師：

教師：在隊中你擔當的角色是什麼？

阿昌： 我是球員及競賽組織委員會的成員。

教師： 你在擔當隊中角色的過程中學到什麼？

阿昌：作為球員，在球場上體驗到隊員與隊員間的鼓 勵及合作精神，例如會踢波的同學會耐心給同 學指導, 而每有錯失, 都能彼此忍耐。作為組 委會成員, 學到了怎樣與其他同學商量去組織 一個比賽。

學生除了認為在隊中所擔當的角色可互相協作外, 在這 模式下，技術水平較低的同學亦可在活動及團隊中得到認同 及接納。阿強是一個被認為足球技術水平較弱的學生, 他對 這足球季有以下的看法：

「我起初很擔心我的表現會連累球隊輸波, 但隊友們 並沒有因此而放棄我, 令我學習到和隊友互相支持和鼓勵的 重要性, 在失球時不要只説隊友的不是, 打擊士氣, 相反要 鼓勵大家。正如在比賽中隊友對我説：『好，這球解圍得 好!』、『唔緊要, 輸呢球唔關你事, 重有時間去追呢! 』 這些的支持亦令我明白到一個整體的合作是很重要的。」

「阿鴻他很好呀! 因他經常敉我幾時要解圍、如何去支 援其他隊友。他有時仲利用放學時間去敉我踢波呢！」

(個人報告一 - - - 嘉豪)

「在這體育課中我不再是被遺棄的一群, 因為我是負責 幫我隊作搜集對隊的情報及作資料分析, 而我亦是隊中的急 救員呢! 由於比賽相當頻密, 有部份隊員抽筋, 我拹助替他 們按摩。課堂過後, 我們更經常一起飯聚、討論比賽中的情 形呢！」(角色訪談 … 平時較不喜歡參與運動者阿明)

這正顯示出在課堂中的學習、互動, 已擴展至在日常 生活如何與別人溝通、協作, 正如Oslin ( 2002 )在其研究 中指出一個長時間的球季、細小的組別及同儕教學能改善低 技能水平的學生的學習, Clake \& Quill （2003 )亦指出 透過在課堂中的學習, 不但讓學生展現其與人合作、領導、 組織的能力, 更重要的是給予機會應用在其他層面上, 如社 際比賽、班際比賽等, 這延伸課程更能發揮此模式的最大功 
效。當然更重要的是讓學生在日常生活上, 明白到與人協 作、溝通藝術的重要性。

除此之外, MacPhail, Kirk \& Kinchin (2004)指出 發展協作及團隊能力是參與運動敎育課程模式的重要成果。 Hastie (1998)亦指出運動敉育模式在中學階段, 學生最能發 展其領導及協作能力, 營造一個正面及鼓勵性的團隊。而在 這研究中亦可發現, 學生在同隊中的協作、不同角色間的協 作亦有所不同。在同隊中的協作能力培養效果更為顯著。以 下是一團隊訪談例子：

敉師: 在小組和球隊中交談時, 能愉快地接受同伴的意 見和建議?

阿誠：起初時我們根本好少交談, 或者是我們隊中有 4 人 是新生吧! 但自從球季展開時, 一項一項的活 動及遊戲將我們拉在一起。我們一齊去訂立自 己的名, 商討不同角色的分工, 當然有時大 家也會有不同的見解, 但不知何解, 我們 最後也總能有一共識, 或者是我們大家也是一 個胸襟廣闊的人吧 (各人相視而笑)

阿龍：哈哈！除此之外, 其實我想主要原因 也是我們想為球隊作最好的準備及貢 獻, 加強我隊的爭勝決心及團隊氣氛呢!

國基： 無錯！如果唔係我們又怎會一起興高采烈地商討 入波後的慶视方式呢! 最後決定以杰仔的「朗拿度 式」入球慶祝方式, 為此我們更積極地在比賽前練 習及在比賽中互相鼓勵及互補不足呢!

呚師：在日常學習和體育活動中, 有什麼例證顯示整隊能 表現出團隊意識嗎?

溥文: 我作為隊中的敎練, 初時實在有很大壓力呢! 因 我也怕敎錯他們。但在帶領他們熱身、練習的過程 中, 整隊人互相協助, 如建立隊型、提點隊友走 位、解釋一些足球術語等, 令我覺得大家很有團隊 精神，十分開心。

阿誠：仲有呀！你唔記得我們在最後一場比賽裏先入了一 球, 大家不斷互相提醒, 十分專注地防守, 希望保 持勝果至完場。那一刻我真的感受到甚麼是萬眾一 心呢!

不過, 在這足球季的協作機會並不單只出現在隊中, 隊 與隊之間的競爭、球證與比賽隊、競賽組織委員會的成員及 與敎練協商亦會出現不同的合作、溝通的機會。當然, 這些 機會對培養學生的協作能力, 均有正面或負面的影響。

「當我們在討論以甚麼賽制進行季尾的比賽時, 各人也 堅持自己所訂立的是最好的, 起初我們也未能有共識, 但後 來諮徇過老師的意見後, 每人也嘗試列寫別人所建議賽制的
優劣之處, 再加以比較, 最終也能得出結果。從中我體會到 與人商討時是需要聆聽及互相溝通、合作, 才能得到最理想 的結果。」(角色訪談 --- 競賽組織委員會成員阿庭)

「在第 1 天的比賽完結後, 我與其餘兩隊的敎練商討, 因為比賽場地實在太大，加上同學的技術不太高，所以希望 把比賽人數改為 8 對 8 的比賽。我其實不太敢於與競賽組織委 員會提出, 因怕他們覺得我踩過界, 但沒想過他們竟也認同 我的理念, 並作出協調。」(角色訪談 --- 敎練溥文)

在這模式中看到，同學彼此間的協作機會多了，因為在 擔當不同角色中, 每人也盡力去履行其角色責任, 但這亦帶 出另一個問題, 凡有人的團隊之中, 總會有是非、爭執的出 現, 這情況亦在此球季中出現。

「在這球季中, 我覺得負面的衝擊主要是來自在比賽中 對球證的不滿，他永遠也不吹哨子或給予任何的指示，明明 對隊踢出界, 但也是對隊開界外球, 唉……」(角色訪談 -.球員阿文)

「我真的不太明白為何鴻生那隊會如此落力, 有時在搶 球時的動作實在有點兒過火, 雖然想贏, 但也應顧及我們的 感受呢! 比賽裏的一些身體碰撞踓然難以避免, 但也至少應 講句唔好意思嘛！」(角色訪談 --- 球員浩文)

一個人的性格對其所作的行為有很大的影響, 當然 亦會影響其與人相處的能力, 研究者相信最主要的原因 是部份學生過於看重自己, 而忽略對其他人的觀感。 $O$ ' Donovan(2003)亦指出部份學生均希望自己隊內不會有些「不 受歡迎的人物」成為自己的隊友, 而越接近決賽期, 勝利比 團隊精神更為重要。因此, 過份看重勝利、過份強調爭勝的 決心, 往往會成為這教學模式下培養協作能力的絆腳石, 因 為各人只為自己, 而忘卻合作的精神, 相信所得出的效果亦 會截然不同。

\section{結論與建緒}

運動敉育模式對學生的學習興趣與協作能力培養起了一 定的影響。經過九個循環週的運動呚育模式學習, 學生對足 球的興趣增加了。影響學生對學習足球的興趣原因有四個, 包括(1) 此敉學模式的過程中, 有很多不同的遊戲讓學生參 與；(2) 課堂中能提供機會讓學生互相學習、互相指導; (3) 學生在球季中能扮演不同角色, 加強學生的自主性, 增加成 功經驗; (4) 球季形式具吸引力, 決賽時期把整個球季的歡 愉氣氛推至最高峯。

運動敉育模式能培養各隊隊員(學生)協作能力。最主要 的原因是學生在過程中有一共同目標, 隊員之間為達至共同 目標而努力。各隊隊員互相交流、協調合作, 因應每隊中不 
同能力的學生一起學習, 藉此發揮團隊合作的精神, 以達成 學習目標。這正和李勝雄(2002)所強調的運動敎育模式中的 集團式學習互相呼應, 使學習者更容易達到溝通協調、组 織、合作等學習目標。

事實上，在隊與隊的協作、不同角色間之協作則受學生 之性格及爭勝心之影響。這研究顯示, 運動敉育對不同隊、 角色間之協作均有正面或負面影響, 究其原因, 主要是不同 角色所負責的任務亦有所不同, 而各人為盡其職, 有時會堅 持已見, 如性格較為固執、獨裁的學生更會影響與人協作之 能力。若爭勝心過於強烈, 亦會影響到隊與隊之間體現體育 精神及人際關係, 因此敉師在呚學實施時, 須留意及敉導學 生平衡處理勝利與體育精神的觀念, 以免影響其與人協作能 力之發展。

根據本研究的過程與結果, 研究者提出以下幾點建議:

\section{連動教育未秝之推廣}

將運動敉育課堂模式納入體育教師培訓課程中, 讓更多 準老師有機會接受新敉學方式, 培育多元化的體育師資。建 議增加運動敉育課堂模式相關研習、研討會及工作坊, 亦可 透過試敉及敉師觀課以利於在職敉師對運動敉育課堂模式的 概念與實施方法有所認識, 最重要的是讓各體育敉師反思日 常的課堂敉學模式, 從而更新自己的敉學, 正如Kirk(2004)指 出建設一個有質素的課堂應能把學生與學習互相掛鈎, 包括 課堂內、外的學習, 甚至乎是生活上的應用。敉師在試行這 課堂模式時, 要留意球季的長短及連貫性, 可先考虑在高年 級試行, 亦可在某一、兩班先試行。而在場地安排上, 建議 最好應有 2 個籃球場作敉學, 因很多不同的分組遊戲是需要 足夠空間, 才可滿足各學生需要及能積極參與。

\section{蓮動教育後續研究之建儎}

本研究主要是以中六級的男生為研究對象, 建議在未來 的研究上, 可安排相同的球類運動以此模式教學, 探討對不 同年級的學生的學習興趣及協作能力之影響, 以理解這模式 對哪個年歲組別的學生的學習興趣及協作能力有最為正面及 有效影響。本研究的受試對象主要為男生, 其全面性或受到 質疑, 在未來的研究上可考虑以此模式敎授女生及男女生混 合對其學習興趣及協作能力之影響, 以加強其全面性。運動 教育課堂模式乃結合不同之教學法去施教, 如合作學習法、 同儕敉學(Metzler，2000)等。然而是否有其他的敉學方法更 能發揮此模式的精神? Holt(2005)亦提出將不同的敉學模式結 合, 也許更能幫助學生運動的發展, 如能在研究上採取量化 結合質性的研究設計, 深入探討以不同敉學法結合這模式對 學生的影響。本研究只探討運動敉育課堂模式對學生協作能 力之影響, 然而在敉育改革中所強調的九種共通能力, 在是 次研究中並没有一一作出深入探究。在未來的研究上可包含 更多有關此模式如何影響學生發展不同共通能力如創造力、 批判思考能力等。

\section{參考文獻}

Alexander, K., Taggart, A., \& Thorpe, S. (1996). A spring in their steps? Possibilities for professional renewal through sport education in Australian schools. Sport, Education and Society, 1(1), 23-46.

Alexander, K., \& Luckman, J. (2001). Australian teachers' perceptions and uses of the sport education curriculum model. European Physical Education Review, 7(3), 243-267.

Armstrong, N., Balding, J., Gentle, P., \& Kirby, B. (1990). Pattern of physical activity among 11to 16 year old British children. British Medical Journal, 301(6745), 203-205.

Bennett, G., \& Hastie, P. (1997). A sport education curriculum model for a collegiate physical activity course. Journal of Physical Education, Recreation, \& Dance, 68(1), 39-43.

Browne, T. B. J., Carlson, T. B., \& Hastie, P. A. (2004). A comparison of rugby seasons presented in traditional and sport education formats. European Physical Education Review, 10(2), 199-214.

Carlson, T. B., \& Hastie, P. A. (1997). The student social system within sport education. Journal of Teaching in Physical Education, 16(2), 176-195.

Hastie, P. A. (1998A). Applied benefits of the sport education model. Journal of Physical Education, Recreation, \& Dance, 69(4), 24-26.

Hastie, P. A. (1998B). The participation and perceptions of girls within a unit of sport education. Journal of Teaching in Physical Education, 17(3), 157-171.

Hastie, P. A. (2000). An ecological analysis of a sport education season. Journal of Teaching in Physical Education, 19(3), 355-373.

Holt, B. (2005). Designing game for sport education: Curricular models. Strategies, 18(4), 25-27.

Jewett, A. E., Bain, L. L., \& Ennis, C. D. (1995). The curriculum process in physical education. Dubuque, Iowa: Brown \& Benchmark. 
Clake, G., \& Quill, M. (2003). Researching sport education in action: A case study. European Physical Education Review, 9(3), 253-265.

Grant, B. C. (1992). Integrating sport into the physical education curriculum in New Zealand secondary schools. Quest, 44(3), 304-316.

Greenockle, K. M., Lee, A. A., \& Lomax, R. (1990). The relationship between selected student characteristics and activity patterns in a required high school physical education class. Research Quarterly for Exercise and Sport, 61(1), 59-69.

Kinchin, G., Penney, D., \& Clarke, G. (2001). Teaching the National Curriculum physical education: Try sport education. The British Journal of Physical Education, $32(2), 41-45$.

Kirk, D. (2004). Framing quality physical education: The elite sport model or sport education? Physical Education and Sport Pedagogy, 9(2), 185-195.

Lincolin, Y. S., \& Guba, E. G. (1985). Naturalistic inquiry. Beverly Hills, CA: Sage.

Lund, J. L., \& Kirk, M. F. (2002). Performance-based assessment for middle and high school physical education. Champaign, IL: Human Kinetics.

MacPhail, A., Kirk, D., \& Kinchin, G.. (2003). Students' conceptions of sport and sport education. European Physical Education Review, 9(3), 285-299.

MacPhail, A., Kirk, D., \& Kinchin, G.. (2004). Sport education: Promoting team affiliation through physical education. Journal of Teaching in Physical Education, 23(2), 106-122.

Metzler, M.W. (2000). Instructional models for physical education. Boston, MA: Allyn and Bacon.

Mohr, D. J., Townsend, J. S., \& Bulger, S. M. (2001). A pedagogical approach to sport education season planning. Journal of Physical Education, Recreation, \& Dance, 72(9), 37-46.
O'Donovan, T. M. (2003). A changing culture? Interrogating the dynamics of peer affiliations over the course of a sport education season. European Physical Education Review, 9(3), 237-250.

Oslin, J. (2002). Sport Education: Cautions, considerations, and celebrations. Journal of Teaching in Physical Education, 21(4), 419-426.

Siedentop, D. (1994). Sport education: Quality PE through positive sport experiences. Champaign, IL: Human Kinetics.

Siedentop, D. (2002). Sport education: A retrospective. Journal of Teaching in Physical Education, 21(4), 409-417.

Siedentop, D., \& Kinchin, G. D. (2003). What makes sport education different? The British Journal of Teaching Physical Education, 34(2), 10-11.

Sinslnikov, O. A., \& Hastie, P. A. (2005). Bicycle safety sport education style. Journal of Physical Education, Recreation, \& Dance, 76(2), 24-29.

Strauss, A. L., \& Corbin, J. (1990. Basics of qualitative research: Grounded theory, procedures and technique. Newsbury Park: Sage Publication.

Townsend, J. S., Mohr, D. J., Rairigh, R. M., \& Bulger, S. M. (2003). Assessing student outcomes in sport education: A pedagogical approach. Reston, VA: National Association for Sport and Physical Education.

Wallhead, T. L., \& Ntoumanis, N. (2004). Effects of a sport education intervention on students' motivational responses in physical education. Journal of Teaching in Physical Education, 23(1), 4-18.

Fraenkel, J. R., \& Wallen, N. E. (2003) : 《教育研究 法：研究設計實務》, 台北, 美商麥格羅. 希爾國 際股份有限公司。

王文科 (2000) : 《質的敉育研究法》, 台北, 師大書苑 有限公司。 
何子安 (2002)：運動敉育模式與社會發展之初探, 《中華體 育》16(2)，頁109-114。

李勝雄 (2002)：《健康與體育教學策略》, 台北, 五南圖書 出版有限公司。

吳明安 (2004) : 運動敉育模式應用在大專體育課程之規劃, 《大專體育》73, 頁32- 40。

胡立仕 (2004)：《老年人運動行為之研究》, 國立台灣師範 大學運動與休閒管理研究所碩士論文, 未出版。

高鳳華 (2004): 為學生創造個性發展的空間, 《中國學校體 育》6, 頁12-13。

曾智豐 (2003)：運動敉育模式之研究, 《大專體育》 69 , 頁 $14-20$ 。
劉軍利 (2003)：體育敎學中運用體育遊戲的探討, 《體育呚 學》1, 頁26。

課程發展議會 (2001)：《學會學習: 終身學習, 全人發 展》, 香港，香港政府印務局。

課程發展議會 (2002)：《體育---學習領域課程指引 (小一至 中三)》，香港，政府印務局。

顏政通、邱文信 (2004) : 創造思考的體育教學活動, 《大專 體育》72，頁12-18。

\section{Correspondence}

Dr. Alberto Cruz

Email: acruz@ied.edu.hk 